\title{
Hubungan asam urat dan HbA1c pada penderita diabetes melitus tipe 2 yang dirawat inap di RSUP Prof. Dr. R.D. Kandou Manado
}

\author{
${ }^{1}$ Guntur \\ 2 Jeffrey Ongkowijaya \\ ${ }^{2}$ Frans E. Wantania
}

\author{
${ }^{1}$ Kandidat Skripsi Fakultas Kedokteran Universitas Sam Ratulangi Manado \\ ${ }^{2}$ Bagian Ilmu Penyakit Dalam Fakultas Kedokteran Universitas Sam Ratulangi Manado \\ Email: gunturbrayen@gmail.com
}

\begin{abstract}
Abstrak: Diabetes mellitus is a metabolic disorder with characteristics of hyperglycemia that occurs due to abnormalities in insulin secretion, action or both. Uric acid is the end product of purine metabolism. Uric acid has been identified as a marker for a metabolic number and hemodynamic abnormalities. In diabetic patients, there is biochemical interaction between serum glucose and purine metabolism, with increased excretion of uric acid during hyperglycemia and glycosuria. Another theory explained that the increase of inflammatory response on diabetes mellitus may have a direct protective effect toward incidences of gout and hyperuricemia which directly produces an intense inflammatory response on uric crystallines containing antioxidant effects and free radical. $\mathrm{HbA1C}$ is a bond between glucose and hemoglobin. HbA1c examination is a standard for measuring the long-term glycemic value in diabetic patients. This study was aimed to determine the correlation of uric acid and $\mathrm{HbA} 1 \mathrm{C}$ in patients with type 2 diabetes mellitus. The study was an analytical cross sectional. Sample selection was done by simple random sampling method. Data sources were secondary data from medical records of patients with type 2 diabetes mellitus who are hospitalized. The result of Spearman correlation analysis on the correlation of uric acidand HbA1C showed $r$ value $=-0.211$ and $p=0.263(p>\alpha)$. Conclusion: There was no correlation between uric acid and HbA1C in patients with type 2 diabetes mellitus.
\end{abstract}

Keywords: Type 2 diabetes mellitus, uric acid, $\mathrm{HbA1C}$

\begin{abstract}
Abstrak: Diabetes melitus merupakan suatu kelompok metabolik dengan karakteristik hiperglikemia yang terjadi karena kelainan sekresi insulin, kerja insulin atau keduanya. Asam urat merupakan produk akhir metabolisme purin. Asam urat telah diidentifikasi sebagai penanda dari beberapa abnormalitas metabolik dan hemodinamik. Pada pasien diabetes melitus, dijumpai interaksi biokimiawi antara glukosa serum dan metabolisme purin, dengan peningkatan ekskresi asam urat selama hiperglikemia dan glikosuria. Teori lain menjelaskan bahwa meningkatnya respons inflamasi pada DM mungkin secara langsung justru memiliki efek protektif terhadap kejadian gout dan hiperurisemia yang secara langsung menghasilkan respons inflamasi yang intens terhadap kristal urat yang memiliki efek anti oksidan dan radikal bebas. HbA1C merupakan ikatan antara glukosa dengan hemoglobin. Pemeriksaan HbA1C merupakan standard dalam pemeriksaan kadar gula darah jangka panjang pada penyandang diabetes. Penelitian ini bertujuan untuk mengetahui hubungan asam urat dan $\mathrm{HbA1C}$ pada penderita diabetes melitus tipe 2. Jenis penelitian ialah analitik dengan desain potong lintang. Pemilihan sampel dilakukan dengan metode simple random sampling. Sumber data merupakan data sekunder dari data rekam medik pasien diabetes melitus tipe 2 yang dirawat inap. Hasil analisis korelasi spearman pada hubungan asam urat dengan $\mathrm{HbA1c}$ memperoleh nilai $r=-0,211$ dan $\mathrm{p}=0,263(\mathrm{p}>\alpha)$. Simpulan: Tidak terdapat hubungan asam urat dengan $\mathrm{HbA1C}$ pada penderita diabetes melitus tipe2.
\end{abstract}

Kata kunci: diabetes melitus tipe 2, asam urat, $\mathrm{HbA} 1 \mathrm{C}$ 
Asam urat merupakan produk akhir metabolisme purin yang berasal dari dalam tubuh/ faktor endogen (genetik) dan berasal dari luar tubuh/ faktor eksogen (sumber makanan). Asam urat dihasilkan oleh setiap mahkluk hidup sebagai hasil dari proses metabolisme sel yang berfungsi untuk memelihara kelangsungan hidup. ${ }^{1}$

Asam urat terutama diekskresikan melalui ginjal, dimana akan terfiltrasi keseluruhan di glomerulus, direabsorbsi di tubulus proksimal, lalu disekresikan dan akhirnya direabsorbsi kembali sebagian; sekitar $10 \%$ akan diekskresikan. ${ }^{2}$

Pada keadaan normal, kadar asam urat serum pada laki-laki mulai meningkat setelah pubertas. Pada perempuan, kadar asam urat tidak meningkat sampai setelah menopause karena estrogen meningkatkan ekskresi asam urat melalui ginjal. Setelah menopause, kadar asam urat serum meningkat seperti pada pria. Nilai normal asam urat serum pada laki-laki adalah 5,1 $\pm 1,0 \mathrm{mg} / \mathrm{dl}$ dan pada perempuan adalah $4,0 \pm 1,0 \mathrm{mg} / \mathrm{dl}^{3}$

Diabetes melitus merupakan suatu gangguan metabolik dengan karakteristik hiperglikemia yang terjadi karena kelainan sekresi insulin, kerja insulin atau keduanya. World Health Organization (WHO) sebelumnya telah merumuskan bahwa DM merupakan sesuatu yang tidak dapat dituangkan dalam satu jawaban yang jelas dan singkat tetapi secara umum dapat dikatakan sebagai suatu kumpulan problema anatomik dan kimiawi akibat dari sejumlah faktor dimana didapat defisiensi insulin absolut atau relatif dan gangguan fungsi insulin. ${ }^{4}$

Diabetes Melitus tipe 2 merupakan tipe diabetes yang lebih umum, lebih banyak penderitanya dibandingkan dengan DM tipe 1. Penyebab dari DM tipe 2 karena selsel sasaran insulin gagal atau tak mampu merespon insulin secara normal, keadaan ini disebut resistensi insulin. Disamping resistensi insulin, pada penderita DM tipe 2 dapat juga timbul gangguan sekresi insulin dan produksi glukosa hepatik yang berlebihan. Namun demikian, tidak terjadi kerusakan sel-sel $\beta$ Langerhans secara autoimun sebagaimana terjadi pada DM tipe 1. Angka kejadian DM tipe 2 di Indonesia berkisar antara 1,4 sampai 1,6\%, kecuali di dua tempat yaitu Pekajangan, suatu desa dekat semarang, 2,3\% dan di Manado 6\%. ${ }^{5}$

Komplikasi pada DM dapat mengenai beberapa organ. Bukti-bukti menunjukkan bahwa komplikasi diabetes dapat dicegah dengan kontrol glikemik yang optimal. Kontrol glikemik yang optimal yaitu terkendalinya konsentrasi glukosa dalam darah, HbA1c (hemoglobin terglikosilasi), kolesterol, trigliserida, status gizi dan tekanan darah. $^{6}$

HbA1c merupakan ikatan antara glukosa dengan hemoglobin. HbA1c yang terbentuk dalam tubuh akan disimpan dalam sel darah merah dan akan terurai secara bertahap bersama dengan berakhirnya masa hidup sel darah merah (rata-rata umur sel darah merah adalah 120 hari). Pengobatan diabetes bisa dikatakan berhasil jika glukosa darah puasa 80 sampai 109 mg/dl, kadar glukosa darah dua jam 80 sampai $144 \mathrm{mg} / \mathrm{dl}$ dan kadar HbA1c $<7 \%$. Pengukuran HbA1c adalah cara yang paling akurat untuk menentukan tingginya kadar gula darah selama 3-4 bulan terakhir. HbA1c juga merupakan pemeriksaan tunggal terbaik untuk menilai risiko terhadap kerusakan jaringan yang disebabkan oleh tingginya kadar gula darah. $^{7}$

Kadar serum asam urat pada awal diabetes dan berdiri sendiri tanpa pengaruh lain secara signifikan diasosiasikan dengan perkembangan makroalbuminuris yang persisten. Oleh karena itu, asam urat bisa menjadi suatu hal yang baru memainkan peranan penting dalam patogenesis dari komplikasi mikrovaskular pada diabetes. ${ }^{8}$

Penelitian di Korea menemukan bahwa kadar asam urat serum yang tinggi berhubungan positif dengan adanya sindrom metabolik. Selain itu juga, kadar serum asam urat memiliki hubungan dengan variable-variabel yang diteliti pada penelitian tersebut seperti kolesterol total, glukosa puasa dan HbA1c. ${ }^{9}$

Berdasarkan uraian diatas, maka penulis 
tertarik untuk mengetahui hubungan asam urat dan HbA1c pada penderita DM tipe 2 khususnya yang dirawat inap di RSUP. Prof. Dr. R. D. Kandou.

\section{METODE PENELITIAN}

Jenis penelitian ini ialah analitik dengan desain potong lintang yang dilakukan pada bulan SeptemberNovember 2016. Pengambilan sampel dilakukan di RSUP Prof. Dr. R.D. Kandou Manado dengan metode simple random sampling dan pemeriksaan sampel dilakukan di Laboratorium RSUP. Prof. Dr. R.D. Kandou.

\section{HASIL PENELITIAN}

Sampel pada penelitian ini berjumlah 30 pasien yang terdiri dari 18 laki-laki dan 12 perempuan dengan diagnosis DM tipe 2 yang dirawat inap di RSUP Prof. Dr. R. D. Kandou.

Tabel 1. Karakteristik sampel secara umum

\begin{tabular}{llllll}
\hline & n & Min & Maks & Rerata & SB \\
& & & & & \\
\hline Umur & 30 & 41 & 85 & 59,77 & 10,59 \\
Asam urat & 30 & 2,9 & 16,4 & 7,65 & 3,20 \\
HbA1C & 30 & 6 & 17 & 9,24 & 2,98 \\
\hline
\end{tabular}

Pada penelitian ini didapatkan usia subjek penelitian bervariasi mulai dari 41 hingga 85 tahun, dengan rerata 59,77 dan simpangan baku 10,59. Berdasarkan nilai asam urat didapatkan nilai terendah 2,9 $\mathrm{mg} / \mathrm{dL}$ dan tertinggi $16,4 \mathrm{mg} / \mathrm{dL}$ dengan rerata 7,65 dan simpangan baku 3,20. Berdasarkan nilai HbA1C didapatkan nilai terendah $6 \%$ dan tertinggi $17 \%$ dengan rerata 9,24 dan simpangan baku 2,98.

Uji normalitas dilakukan untuk mengetahui distribusi data penelitian. Data penelitian dianalisis dengan Shapiro-Wilk Test. Uji normalitas yang digunakan adalah uji shapiro-wilk karena jumlah sampel (n) $<40$.

Berdasarkan Tabel 2, didapatkan hasil uji normalitas untuk data asam urat ialah $p$-value $=0,018$ dengan nilai $\alpha=0,05$ yang menunjukkan data asam urat berdistribusi tidak normal. Berdasarkan data $\mathrm{HbA} 1 \mathrm{C}$ didapatkan $p=0,001$ dengan nilai $\alpha=0,05$ yang menunjukkan data HbA1C berdistribusi tidak normal. Dengan demikian, disimpulkan bahwa analisa data selanjutnya akan menggunakan uji nonparametrik Spearman.

Tabel 3. Hasil analisis hubungan asam urat dengan HbA1C dengan menggunakan Uji Spearman Rank Correlation

\begin{tabular}{lclc}
\hline Variabel & n & $\begin{array}{l}\text { Spearman- } \\
\text { rho }\end{array}$ & p \\
\hline $\begin{array}{l}\text { Asam urat } \\
\text { dan }\end{array}$ & 30 & $-0,211$ & 0,263 \\
HbA1C & & & \\
\hline
\end{tabular}

Tabel 3 merupakan hasil interpretasi analisis hubungan lingkar pinggang dengan kadar gula darah dimana diperoleh $\mathrm{p}=$ $0,263(\alpha=0,05)$ yang memnunjukkan tidak terdapat hubungan bermakna antara asam urat dan HbA1C. Tabel 3 juga menampilkan nilai korelasi data, yaitu 0,211 yang menunjukan korelasi antara asam urat dan $\mathrm{HbA1C}$ lemah dan bernilai negatif.

\section{BAHASAN}

Penelitian ini bertujuan untuk mengetahui adanya hubungan antara asam urat dengan $\mathrm{HbA} 1 \mathrm{C}$ pada penderita DM tipe 2. Terdapat 30 sampel yang memenuhi kriteria inklusi dan eksklusi. Kebanyakan sampel berjenis kelamin laki-laki (60\%). Sampel yang ada ini kemudian diambil data hasil pemeriksaan laboratorium yaitu asam urat dan $\mathrm{HbA} 1 \mathrm{C}$.

Setelah dilakukan penelitian, dari 30 sampel pasien DM tipe 2 didapatkan 25 pasien memiliki kadar HbA1C yang tidak terkontrol yaitu diatas 7\%. Selain itu juga didapatkan rata-rata kadar HbA1C berada diatas normal yaitu 9,24. Kadar HbA1C yang tidak terkontrol dapat menyebabkan komplikasi, oleh Karena itu bagi penyandang diabetes, ADA (American Diabetes Association) merekomendasikan bahwa kadar HbA1C dinyatakan terkontrol apabila berada $<7 \%$ dan tidak terkontrol jika $>7 \% .^{10}$ 
Pada penelitian ini juga didapatkan 9 pasien dengan kadar asam urat yang tinggi ( >6 mg/dL) dan 11 pasien dengan kadar asam urat yang normal $(<6 \mathrm{mg} / \mathrm{dL})$, dengan nilai rata-rata kadar asam urat berada diatas normal yaitu 7,65.

Secara rata-rata, peningkatan kadar HbA1C sebanding dengan peningkatan kadar asam urat, namun secara statistik, setelah dilakukan uji korelasi dengan uji Spearman-rank correlation terhadap data, didapatkan $\mathrm{p}=0,263$ yang membuktikan tidak ada hubungan bermakna antara asam urat dengan $\mathrm{HbA} 1 \mathrm{C}$.

Penelitian serupa ini juga dilakukan oleh Kandaswamy et al. ${ }^{11}$ dengan menggunakan 135 sampel yang mendapatkan terdapat hubungan antara asam urat dengan HbA1C. Pada awalnya peningkatan asam urat diikuti juga oleh peningkatan $\mathrm{HbA} 1 \mathrm{C}$ namun kemudian akan menurun ketika HbA1C meningkat lebih lanjut. ${ }^{11}$

Ada beberapa hipotesis yang menjelaskan hubungan antara asam urat dengan HbA1C diantaranya adalah pada pasien diabetes melitus, dijumpai interaksi biokimiawi antara glukosa serum dan metabolisme purin, dengan peningkatan ekskresi asam urat selama hiperglikemia dan glikosuria. ${ }^{12}$ Teori lain yang dapat menjelaskan hal ini adalah meningkatnya respons inflamasi pada DM mungkin secara langsung justru memiliki efek protektif terhadap kejadian gout dan hiperurisemia yang secara langsung menghasilkan respons inflamasi yang intens terhadap kristal urat yang memiliki efek anti oksidan dan radikal bebas. ${ }^{13}$

Tidak adanya hubungan antara asam urat dengan $\mathrm{HbA1C}$ pada penelitian ini dapat disebabkan oleh beberapa faktor antara lain kurangnya sampel penelitian. Dari segi metodologi penelitian, jumlah sampel yang semakin banyak akan meningkatkan peluang hubungan antar variabel. Selain itu juga tidak adanya penilaian langsung terhadap faktor yang dapat mempengaruhi penghasilan level asam urat baik dalam katabolisme purin, dan respon sistemik inflamasi kronis karena adanya kontrol metabolik yang buruk dan juga hiperfiltrasi di ginjal juga menjadi salah satu faktor yang mempengaruhi hasil analisis data.

\section{SIMPULAN}

Dari hasil penelitian dapat disimpullkan bahwa tidak terdapat hubungan antara asam urat dan $\mathrm{HbA} 1 \mathrm{C}$ pada penderita DM tipe 2 yang dirawat inap di RSUP Prof. Dr. R. D. Kandou.

\section{SARAN}

1. Penelitian selanjutnya diharapkan menggunakan sampel yang lebih banyak sehingga dapat lebih meningkatkan peluang hubungan antar variabel.

2. Penelitian selanjutnya diharapkan melibatkan variabel yang berbeda sehingga hasil penelitian selanjutnya lebih luas, contohnya dengan mengelompokkan pasien DM Tipe 2 yang $\mathrm{HbA} 1 \mathrm{C}$ terkontrol atau tidak.

3. Penelitian selanjutnya diharapkan melakukan penilaian langsung terhadap faktor-faktor yang dapat memengaruhi penghasilan level asam urat.

\section{DAFTAR PUSTAKA}

1. Kanbara, A., Hakoda, M., Seyama I. Urine Alkalization facilitates uric Acid Excretion. Nutritional Journal 2010, 9: doi 10.1186/1475-289145.

2. Bergamini C, Cicoira M, Rossi A, Vassanelli C. Oxidative stress and hyperuricemia: Pathophysiology, Clinical relevance, and therapeutic implication in chronic heart failure. European Journal of Heart Failure. 2009;11:444-52.

3. Michael A. Gout. In: Price SA, Wilson LM, editors. Patofisiologi konsep klinis proses-proses penyakit (6th ed). Jakarta. EGC; 2005. h. 1402-3.

4. Purnamasari D. Diagnosis dan klasifikasi diabetes melitus. In: Setiati S, Alwi I, Sudoyo AW, Marcellus SK, Setiyohadi B, Syam AF, editors. Ilmu Penyakit Dalam. Edisi VI. Jakarta. InternaPublishing; 2014. h. 2323-27.

5. Suyono S. Diabetes melitus di Indonesia. In: Setiati S, Alwi I, Sudoyo AW, Marcellus SK, Setiyohadi B, Syam 
AF, editors. Ilmu Penyakit Dalam (6th ed). Jakarta. InternaPublishing, 2014; p, 2315-22.

6. Qurratuaeni. Faktor-faktor yang berhubungan dengan terkendalinya kadar gula darah pada pasien diabetes melitus di rumah sakit umum pusat (RSUP) fatmawati Jakarta [Skripsi]. Jakarta: Fakultas Kedokteran dan Ilmu Kesehatan UIN Syarif Hidayatullah; 2009.

7. Rismayanthi C. Terapi insulin sebagai alternatif pengobatan bagi penderita diabetes. [cited 27 Agustus 2016]. Available from: http://www.academia.edu/8077318/T ERAPI_INSULIN_SEBAGAI_ALTE RNATIF_PENGOBATAN_BAGI_P ENDERITA_DIABETES.

8. Peter Hovind, D., Peter Rossing, Richard, J., Johnson, Hans-Henrik Parving. Serum Uric Acid as a New Player in the Development of Diabetic Nephropathy. J. Ren. Nutr. 2011;21(1):124-7.

9. Lee JM, Kim HC, Cho HM, Oh SM, Choil PC, Suh. Association between serum uric acid level and metabolic syndrome. J Prev Med Public Health. 2012;45:181-7.

10. American Diabetes Association (ADA). Standards of medical care in diabetes. Diabetes Care: 27; 2004.

11. Kandaswamy VC, Rangasamy S, Panneerselvam S. Serum adenosine deaminase activity - does it predict glycaemic status in type 2 diabetes mellitus. J Evid Based Med Healthc. 2016;3(28):1288-91.

12. Sudhindra Rao M, Bino John Sahayo. A Study of Serum Uric Acid in Diabetes Mellitus and Pre-Diabetes in a South Indian Tertiary Care Hospital. Nitte University Journal of Health Sciences. 2012;2 (2):18-23.

13. Choi HK, Ford ES. Hemoglobin A1c, fasting glucose, serum C-peptide and insulin resistance in relation to serum uric acid levels the Third National Health and Nutrition Examination Survey. Rheumatology. 2008;47:7137. 